\title{
A NEW POTENT ANALOGUE OF NISENTIL
}

J. Lee, Ph D., W. M. Benson, M.D., PH.D., and F. F. Foldes, M.D. *

Previous work has shown that the diastereomeric 1,3-dimethyl-4-phenyl-4-propionoxypipendines have powerful analgetic activity in experimental animals ( 1 ). The $a$-dıastereomer, Ro 2-1196 (= alphaprodine hydrochloride $=$ Nisen$\mathrm{tal}\left(\mathrm{B}^{\mathrm{HCl}}\right.$ ), is less active (about equal to morphne in rats) but better tolerated than the $\beta$-drastereomer, Ro 2-1779, and was introduced commercially as a shortacting analgetic $(2,3,4)$.

TABLE I

1-METHYL-3-SUBSTTIUTED-4-PHENYL-4-ACYLOXYPIPERIDINES<smiles>[R]C(=O)OC1(CCCC)CCN(C)CC1[R]</smiles>

\begin{tabular}{|c|c|c|c|c|c|c|}
\hline $\begin{array}{l}\text { Compound } \\
\text { Ro 2- }\end{array}$ & $\mathrm{R}$ & $\mathrm{R}^{1}$ & $\mathrm{HX}$ & $\begin{array}{c}\text { M P } \\
\text { (corrected) }\end{array}$ & $\begin{array}{c}\mathrm{AD}_{50} \\
\text { (Intrave } \\
\text { in mice, } \mathrm{n}\end{array}$ & $\begin{array}{l}\mathrm{LD}_{\tilde{5} 0} \\
\text { enously } \\
\mathrm{mg} / \mathrm{kg}\end{array}$ \\
\hline 1196 & methyl $(\alpha) \dagger$ & propionoxy & hydrochlonde & $220-221$ & 080 & 510 \\
\hline 1779 & methyl $(\beta) \dagger$ & propionoxy & hydrochlonde & $200-201$ & 030 & 548 \\
\hline 1932 & ethyl ${ }^{\circ}$ & propionoxy & hydrochlonde & 230 & 074 & 450 \\
\hline 7113 & allyl $(\alpha)$ & propionoxy & hydrochlonde & $185-186$ & 007 & 457 \\
\hline 7839 & allyl $(\beta)$ & propionoxy & hydrochlonde & 202-203 & 026 & 530 \\
\hline 7825 & allyl $(\alpha)$ & butyroxy & hydrochloride & $151-152$ & 025 & 375 \\
\hline 7826 & allyl $(\alpha)$ & acetoxy & hydrochloride & $211-212$ & 045 & -675 \\
\hline 7176 & n-propyl $(\alpha)$ & propionoxy & hydrochloride & $203-205$ & 225 & 480 \\
\hline 7142 & dibromoallyl $(\alpha)$ & propionoxy & hydrochloride & $182-183$ & 136 & 530 \\
\hline 7471 & $\operatorname{crotyl}(\alpha)$ & propionoxy & d-tartrate & $95-97$ & 2840 & 575 \\
\hline 7483 & $\operatorname{crotyl}(\beta)$ & propionoxy & maleate & $126-130$ & 2150 & 535 \\
\hline 7482 & n-butyl & propionoxy & d-tartrate & $140-143$ & 2000 & 415 \\
\hline 7516 & n-hexyl* & propionoxy & dl-malate & $98-100$ & 2000 & 275 \\
\hline $7994 / 1$ & benzyl ${ }^{*}$ & propionoxy & hydrochlonde & $207-208$ & 240 & 390 \\
\hline
\end{tabular}

* Relative configuration unknown-probably $(\alpha)$

* Tested as dl-malate (water soluble, non-crystalline)

tOther pharmacological results published in (1)

-Departments of Chemical and Pharmacological Research, Hoffmann-La Roohe Inc, U S A

- Department of Anesthesia, Mercy Hospital, Pittsburgh and the Section of Anesthesiology, Department of Surgery, University of Pittsburgh School of Medicine, Pittsburgh, Pennsylvania, US A 
With the hope of obtaining compounds wtth qualitative and quantative differences in analgetic potency, the structure vas modified to obtam the 1methyl-3-substituted-4-phenyl-4-acyloxy-piperıdines described in Table I, which also presents the values of analgetic activity $\left(\mathrm{AD}_{50}\right)$ and toxicity $\left(L D_{50}\right)$ of the compounds when administered intravenously to mice. Analgesia was assessed by mechanical compression of the tall. All compounds were tested in the form of racemates.

One of these agents, viz, Ro 2-7113 (1-methyl-3-allyl-4-phenyl-4-propionoxypipendine hydrochloride), while of the same order of toxicity as Ro 2-1196, was found to be considerably more actuve. The favourably high ratio between the 50 per cent lethal and analgetic doses is evident from Table II. In rats, Ro 2-7113

TABLE II

Analgetic Actrvity and Toxicity of Ro 2-7113 AND

Ro 2-1196 in Mice, Rats and Rabbits

\begin{tabular}{lccccc}
\hline Animal & Route & $\begin{array}{c}\text { Compound } \\
\text { RO 2- }\end{array}$ & $\begin{array}{c}\mathrm{AD}_{50}^{*} \\
\mathrm{mg} / \mathrm{kg}\end{array}$ & $\begin{array}{c}\text { LD 50 } \\
\mathrm{mg} / \mathrm{kg} .\end{array}$ & $\begin{array}{c}\text { Ratio } \\
\mathrm{LD}_{50} / \mathrm{AD}_{50}\end{array}$ \\
\hline Mice & I V. & 7113 & 007 & 460 & 6530 \\
Rats & I V. & 1196 & 080 & 510 & 638 \\
& I V & 7113 & 005 & 134 & 2680 \\
& IV & 1196 & 062 & 250 & 403 \\
& S C & 7113 & 013 & 800 & 6154 \\
& S C. & 1196 & 100 & 500 & 500 \\
Rabbits & P O & 7113 & 120 & 1250 & 104 \\
& P O & 1196 & 210 & 900 & 43 \\
& I V. & 7113 & 06 & 78 & 1300 \\
& I V & 1196 & 20 & 220 & 110 \\
\hline
\end{tabular}

${ }^{*}$ Calculated in mice and estimated for rats and rabbits For latter species, doses represent those required to prolong reaction time 100 per cent

exhibited a high order of analgetic activity when measured by a modification of the Ercoli and Lews technique (5). The ratio between toxicity and analgesia was greater than that of Ro 2-1196 when the drugs were given intravenously, subcutaneously or orally. In rabbits, comparable results were obtained by the intravenous route of administration, although equivalent degrees of analgesia were associated with similar degrees of respiratory depression when studied by combining the Ercoli and Lews technique for measurement of analgesia and the Wright technique (6) for measuring minute volume exchange. Significant analgetic effects were also demonstrated in the dog.

Clinical trials with Ro 2-7113 were carried out on a limited scale by the oral and intravenous routes. Thirteen ambulatory patients with inoperable malignancies received alternately 2 to $6 \mathrm{mg}$. Ro $2-7113$ or levorphan. The drugs were administered orally, 4 to 8 hours apart, for periods ranging from 4 to 97 days. The onset, duration, and degree of analgesia and the inciderice and severity of 
side effects were recorded following the use of both compounds. A comparative analysis of results could not be made because of the progressive nature of the underlyng pathology. However, the impression was gained that the onset, degree, and duration of action of identical oral doses of Ro 2-7113 and levorphan were quite similar. The incidence of side effects such as drowsiness, vertigo, and nausea was usually lower and the seventy less marked after the administration of Ro 2-7113 than after levorphan. Adminıstered intravenously on a weight basis, Ro 2-7113 was found to be 2 to 3 times, 10 times, and 25 to 30 times more potent than morphine, alphaprodine, and meperidne, respectively. By this route, the duration of action of Ro 2-7113 and alphaprodine was approximately equal. As with other potent narcotic analgetics, large doses of Ro $2-7113$ produced marked respiratory depression which was readily antagonized by levallorphan.

Ro 2-7113, in combination with levallorphan, was used intravenously for supplementation of $\mathrm{N}_{2} \mathrm{O}-\mathrm{O}_{2}$ anaesthesia in 230 patients. The initial dose of Ro 2-7113 was $0.1 \mathrm{mg} / \mathrm{kg}$. and that of the narcotic antagonist, $0.02 \mathrm{mg} / \mathrm{kg}$. The anaesthetic management (7) was the same as that used for 852 patients who received $1 \mathrm{mg} / \mathrm{kg}$. of alphaprodine and $0.02 \mathrm{mg} / \mathrm{kg}$ of levallorphan as initial doses. In these two series, the effects of Ro $2-7113$ and of alphaprodine were identical for all practical purposes

The prelummary observations here reported suggest that Ro 2-7113 may become a clinically useful analgetic.

\section{REFERENCES}

1 Randall, L O \& Lemman, G J Pharmacol 93314 (1948)

2. Hapke, F B \& Barnes, A C Amer J Obstet Gynec 58799 (1949)

3 Sмrтн, E J \& Nagyfy, S F Amer J Obstet Gynec 58695 (1949)

4 Thelen, C" Jackson Clin Bull 11 170 (1949)

5 Ercol, N \& Lewis, M. N J Pharmacol 84301 (1945)

6 Whight, C I J Pharmacol 51.327 (1934)

7 Foldes, F F, Lipschitz E, Weber, G M, Swerdlow, M, \&. Pirk, L A J A M A 160168 (January, 1956) 